\title{
TAKUT AKAN KEGAGALAN SEBAGAI PREDIKTOR PROKRASTINASI AKADEMIK DIMODERASI STATUS IDENTITAS VOKASIONAL MAHASISWA BIDIKMISI UPI
}

\author{
Ira Septiani Iswara*, MIF Baihaqi, dan Helli Ihsan \\ Departemen Psikologi, Universitas Pendidikan Indonesia \\ J1. Dr. Setiabudi No.229, Isola, Kec. Sukasari, Kota Bandung, Jawa Barat 40154 \\ E-mail: iraseptiswara@student.upi.edu
}

\begin{abstract}
ABSTRAK
Penelitian ini bertujuan untuk mengetahui pengaruh takut akan kegagalan terhadap prokrastinasi akademik yang dimoderasi status identitas vokasional pada mahasiswa Bidikmisi Universitas Pendidikan Indonesia. Penelitian dilakukan pada 227 orang mahasiswa Bidikmisi Universitas Pendidikan Indonesia tingkat satu, dua, tiga dan empat menggunakan instrumen Academic Procrastination Scale (APS), The Performance Failure Appraisal Inventory (PFAI), dan Occupational Identity Scale (OIS). Hasil pengumpulan data dianalisis menggunakan metode analisis regresi ganda dan metode Moderated Regression Analysis (MRA) dengan program Statistical Package for Social Sciences (SPSS) versi 25.0 dan Microsoft Excel 2010. Hasil penelitian ini menunjukkan bahwa takut akan kegagalan dapat menjadi prediktor terjadinya prokrastinasi akademik. Status identitas vokasional achievement berperan sebagai quasi moderator, status identitas vokasional moratorium tidak memoderasi, status identitas vokasional foreclosure berperan sebagai pure moderator, dan status identitas vokasional diffusion berperan sebagai variabel intervening pada penelitian ini.
\end{abstract}

Kata kunci: prokrastinasi akademik; takut akan kegagalan; status identitas vokasional; moderasi.

\section{FEAR OF FAILURE AS A PREDICTOR OF ACADEMIC PROCRASTINATION MODERATED BY VOCATIONAL IDENTITY STATUS OF BIDIKMISI STUDENTS AT UPI}

\begin{abstract}
This study aims to determine the effect of fear of failure on academic procrastination which is moderated by vocational identity status in Bidikmisi students at Indonesia University of Education (UPI). The study was conducted on 227 Bidikmisi students at Indonesia University of Education in force year of level one, two, three and four using the Academic Procrastination Scale (APS), The Performance Failure Appraisal Inventory (PFAI), and the Occupational Identity Scale (OIS). The collected research data was analyzed using multiple regression analysis method and the Moderated Regression Analysis (MRA) method with the Statistical Package for Social Sciences (SPSS) program version 25.0 and Microsoft Excel 2010. The results of this study indicates that fear of failure can be a predictor of academic procrastination. The achievement's vocational identity status acts as a quasi moderator, the moratorium's vocational identity status does not moderate, the foreclosure's vocational identity status acts as a pure moderator, and the diffusion's vocational identity status acts as an intervening variable in this study.
\end{abstract}

Keyword: academic procrastination; fear of failure; vocational identity status; moderating. 


\section{PENDAHULUAN}

Mahasiswa merupakan individu yang menempuh jalur pendidikan di perguruan tinggi. Hasil belajar mahasiswa dapat dilihat dari keberhasilan pada prestasi akademik yang diraih serta kemampuan dalam menggunakan waktu sebaik-baiknya (Safitri, 2018). Pengaturan waktu merupakan salah satu persoalan yang dihadapi mahasiswa (Djamarah, 2008). Kurangnya pengaturan waktu pada mahasiswa dapat mengakibatkan munculnya perilaku menunda-nunda (Safitri, 2018). Perilaku menunda-nunda pekerjaan dikenal dengan istilah prokrastinasi. Prokrastinasi yang berkaitan dengan pendidikan disebut prokrastinasi akademik, yaitu kecenderungan perilaku menunda-nunda secara sengaja pada awal dan/atau saat penyelesaian dalam melaksanakan tuntutan akademik dari tenggat waktu yang sudah ditentukan agar dapat menghindari kesulitan (Ferrari, dkk., 1995; McCloskey, 2011; Pradinata \& Susilo, 2016; Setyadi \& Mastuti, 2014).

Salah satu golongan mahasiswa yang kerap kali melakukan prokrastinasi adalah mahasiswa Bidikmisi. Hasil dari artikel media menunjukkan bahwa pada tahun 2015, sebanyak 329 mahasiswa penerima Bidikmisi gagal lulus tepat waktu yang dilaporkan oleh Republika.co.id (Murdaningsih, 2015). Pada tahun 2017 dilaporkan pula sekitar 700 mahasiswa penerima Bidikmisi melewati batas kuliah delapan semester (JPNN.com, 2017). Lamanya masa studi ini menggambarkan adanya penundaan dalam pengerjaan tugas akademik (Pratiwi, 2015; Rozak, 2017). Prokrastinasi akademik dapat mengakibatkan terhambatnya proses kelulusan mahasiswa, terlebih lagi untuk mahasiswa Bidikmisi yang memang memiliki tuntutan lulus tidak lebih dari empat tahun. Mahasiswa penerima Bidikmisi yang tidak lulus tepat waktu selama empat tahun, selanjutnya akan membayar uang kuliah tunggal (UKT) secara pribadi, tidak lagi ditanggung oleh pemerintah (Panduan Bidikmisi, 2018).

Perilaku prokrastinasi akademik ini dapat dipengaruhi oleh faktor eksternal dan faktor internal (Solomon \& Rothblum, 1984). Faktor internal pertama yang paling berkontribusi terhadap prokrastinasi pada mahasiswa adalah takut akan kegagalan, yaitu sebesar 6\% hingga 14\% (Solomon \& Rothblum, 1984). Semakin mahasiswa merasa takut akan kegagalan, semakin besar pula tendensi yang diperlihatkan untuk melakukan prokrastinasi akademik (Akmal dkk., 2017). Takut akan kegagalan dapat menjadi faktor terjadinya prokrastinasi akademik karena mahasiswa merasa takut dinilai buruk pada kompetensi dirinya dan dikritik oleh orang lain, sehingga mereka melakukan prokrastinasi sebagai strategi untuk mengatasi takut akan kegagalan yang dirasakannya (Burka \& Yuen, 2008; Wulan \& Abdullah, 2014). Kegagalan juga dapat menyebabkan dampak psikis seperti rasa kurang percaya diri (Conroy dkk., 2007), menimbulkan keyakinan tidak masuk akal (Chen dkk., 2009), dan kecemasan pada mahasiswa (Athanas, 2007; Conroy dkk., 2007).

Mahasiswa dapat melakukan perilaku tidak masuk akal, seperti tidak melakukan apapun untuk mengembangkan dirinya, karena cenderung menghindari aktivitas yang dapat memicu timbulnya kecemasan (Chen dkk., 2009; Conroy dkk., 2005). Perilaku tidak masuk akal tersebut dapat menurunkan kinerja mahasiswa dalam mencapai tujuan dan mendorong mahasiswa untuk melakukan prokrastinasi akademik (Akmal dkk., 2017; Schuler dkk., 2013; Solomon dan Rothblum, 1984). Hasil penelitian Haghbin, dkk., (2012) menyatakan siswa dengan tingkat kompetensi yang rendah mempunyai kemungkinan yang lebih tinggi untuk mengalihkan perhatian mereka dengan kegiatan yang kurang memicu kecemasan. Hal ini disebabkan oleh keyakinan mereka bahwa konsekuensi dari kegagalan adalah permusuhan dan ancaman sehingga mereka merasakan emosi negatif. Artinya, baik secara kognitif maupun emosional, komponen takut akan kegagalan dapat meningkatkan prokrastinasi. Didukung penelitian Sebastian (2013) yang menghasilkan hubungan positif bahwa seseorang yang memiliki rasa takut akan kegagalan yang tinggi akan cenderung menganggap tugasnya tidak menyenangkan dan menyebabkan ia mudah teralihkan oleh hal lain. Pada akhirnya, individu tersebut akan melakukan prokrastinasi. Di sisi lain, penelitian Schouwenburg (1995) dan Setyadi \& Mastuti (2014) menunjukkan bahwa takut akan kegagalan tidak berkorelasi dengan prokrastinasi akademik pada mahasiswa. Hal tersebut tergantung pada pemilihan subjek, seperti mahasiswa yang berasal dari program akselerasi, tingkat prokrastinasi, dan tingkat dari takut akan kegagalan itu sendiri.

Selanjutnya terdapat penelitian dari Januar (2016) yang menunjukkan bahwa sebagian besar mahasiswa Departemen Psikologi UPI $(73,23 \%)$ mengalami ketakutan akan kegagalan dalam kategori sedang. Dengan kata lain, responden menganggap bahwa kegagalan terjadi bukan hanya karena tidak terwujudnya suatu harapan, usaha yang tidak cukup, serta munculnya emosi negatif pada diri sendiri dan 
orang lain, melainkan kegagalan juga dipersepsikan menjadi motivasi bagi seseorang untuk meraih prestasi. Kemudian, pada penelitian Amanda (2019), dipaparkan bahwa jika mahasiswa memiliki rasa takut akan kegagalan yang tinggi, ia akan cenderung jarang menunjukkan perilaku prokrastinasi menulis skripsi. Meskipun demikian, dalam penelitian ini ditemukan bahwa perilaku prokrastinasi menulis skripsi mahasiswa dapat berubah jika mahasiswa memiliki kondisi dukungan sosial teman sebaya yang berbeda. Jika mahasiswa memiliki dukungan sosial yang tinggi, maka ia akan banyak menunjukkan perilaku prokrastinasi menulis skripsi pula.

Selain takut akan kegagalan, faktor internal lain yang dapat menyebabkan mahasiswa melakukan prokrastinasi akademik adalah status identitas vokasional, identitas dapat memengaruhi pandangan terhadap orientasi masa depan tentang pilihan pendidikan dan preferensi karier, dan tingkah laku di kelas (Flores-Crespo, 2007). Status identitas vokasional adalah ada tidaknya usaha eksplorasi menyangkut berbagai alternatif vokasional dengan ditetapkannya komitmen yang jelas terhadap suatu pilihan pendidikan/karier berlandaskan pertimbangan yang matang. Dengan kata lain, identitas diri telah terbentuk (Marcia dkk, 1993).

Pengembangan identitas ego berkorelasi negatif dengan prokrastinasi. Artinya, semakin banyak seseorang tahu siapa diri mereka, semakin rendah skor mereka pada langkah-langkah prokrastinasi. Hal ini disebabkan oleh mereka mengetahui siapa diri mereka dapat bermanfaat dalam hal pengejaran tujuan diri secara sengaja, membantu memilah prioritas, dan bertindak secara efektif. Selanjutnya, Shanahan \& Pychyl (2007) menambahkan, pengenalan diri juga dikenal sebagai identitas ego, fungsi-fungsi ego ini dianggap penting untuk menentukan pilihan dan kemampuan bertindak. Keyakinan bahwa diri mengendalikan keputusan dan bertanggung jawab atas hasilnya, bergantung pada pengembangan ego dalam identitas diri seseorang.

Bagi mereka yang status identitasnya ada dalam kategori achievement, dapat dijelaskan bahwa eksplorasi dan komitmennya bekerja secara sinergis dalam berkontribusi pada skor prokrastinasi yang lebih rendah (Shanahan \& Pychyl, 2007). Selain itu, terdapat pula orang yang berada pada status identitas moratorium, yaitu orang yang sedang menjelajah, tetapi belum berkomitmen. Kurangnya komitmen ini dapat menghambat kemampuan mereka untuk menerjemahkan peningkatan basis pengetahuan dan pemahaman yang telah diberikan eksplorasi untuk mencapai tujuan yang praktis dan terarah pada waktu yang tepat (Shanahan \& Pychyl, 2007).

Dalam status identitas foreclosure, individu sudah terlebih dulu melakukan komitmen namun belum melakukan eksplorasi (Marcia dkk, 1993). Semakin lama individu mempertahankan identitas foreclosure, semakin besar pula perasaan malu dan perasaan bersalah yang disertai mempertanyakan posisinya (Kroger \& Marcia, 2011). Hasil penelitian menemukan bahwa pembentukan identitas diri foreclosure ditunjukkan dengan kemampuan eksplorasi yang rendah digambarkan dengan kurangnya pengetahuan mengenai tempat pendidikan dan mengikuti keputusan dari sekitar (Asmawati dkk., 2013). Dalam status identitas diffusion, individu tidak melakukan eksplorasi terhadap alternatif-alternatif yang ada dan belum mampu membuat komitmen (Marcia dkk, 1993). Mereka yang berstatus identitas diffusion memiliki aktualisasi diri yang rendah (Sunanto dkk., 2013), dan belum bisa melalui krisis dalam dirinya (Mahmudah, 2013).

Hal ini sejalan dengan penelitian Ramadhani (2016) yang mengatakan bahwa terdapat hubungan antara status identitas vokasional dengan prokrastinasi akademik. Penelitian Ramadhani ini memberikan kesimpulan bahwa mahasiswa dengan status identitas vokasional achievement, moratorium, dan foreclosure melakukan prokrastinasi akademik dengan tingkatan yang rendah, sedangkan mahasiswa dengan status identitas vokasional diffusion melakukan prokrastinasi akademik dengan tingkatan yang sangat tinggi.

Dengan demikian, mahasiswa yang mengalami takut akan kegagalan dengan status identitas achievement, moratorium, dan foreclosure memungkinkan melakukan prokrastinasi akademik dalam tingkat yang rendah, sementara mahasiswa yang mengalami takut akan kegagalan dengan status identitas diffusion, memungkinkan melakukan prokrastinasi akademik dalam tingkat yang tinggi.

Jika kedua variabel takut akan kegagalan dan status identitas vokasional digabungkan, terjadinya prokrastinasi akademik diasumsikan dapat berubah. Namun, penelitian mengenai status identitas vokasional dengan prokrastinasi akademik pada mahasiswa belum banyak dilakukan, di Indonesia sendiri subjek penelitiannya pun masih dalam lingkup salah satu fakultas di satu universitas (FIP UPI). 
Penelitian mengenai takut akan kegagalan dan prokrastinasi akademik pada mahasiswa pun tidak selalu berkorelasi. Hal tersebut menandakan adanya variabel lain yang memengaruhi arah hubungan variabel prediktor dengan variabel kriteria, variabel yang dapat merubah prediktor variabel tersebut dinamakan variabel moderasi (Baron \& Kenny, 1986; Hayes, 2013).

Variabel moderasi adalah variabel untuk mengetahui arah hubungan antar variabel independen dengan dependen yang dapat menghasilkan positif atau negatif tergantung dari variabel moderasi. Jika ada hasil yang berbeda antar kategori tertentu, maka penelitian ini bisa disebut sebagai moderasi (Hayes, 2018). Dalam penelitian ini, variabel status identitas vokasional berperan sebagai variabel moderasi pada takut akan kegagalan sebagai prediktor terjadinya prokrastinasi akademik. Maka dari itu, peneliti bermaksud untuk mencari tahu apakah status identitas vokasional dapat memoderasi takut akan kegagalan sebagai prediktor prokrastinasi akademik pada mahasiswa Bidikmisi Universitas Pendidikan Indonesia.

\section{METODE}

Penelitian ini menggunakan pendekatan kuantitatif-korelasional. Responden sebanyak 227 orang remaja akhir di kampus UPI dipilih berdasarkan teknik stratified random sampling. Dalam melakukan pengambilan data, peneliti menyebarkan kuesioner secara daring pada responden dengan kriteria remaja akhir berusia 18 s.d. 22 tahun. Pengukuran takut akan kegagalan menggunakan instrumen The Performance Failure Appraisal Inventory (PFAI) yang dikembangkan oleh David E Conroy (2002) kemudian diadaptasi oleh Intan Salindri Galiesta (2017) dengan skor reliabilitas sebesar 0,82. Instrumen PFAI terdiri dari 25 item berdasarkan lima dimensi yang memiliki empat poin alternatif jawaban, yaitu sangat sesuai (SS), sesuai (S), tidak sesuai (TS), dan sangat tidak sesuai (STS). Kemudian, untuk mengukur prokrastinasi akademik menggunakan instrumen Academic Procrastination Scale (APS) yang dikembangkan oleh McCloskey (2011) dan diadaptasi oleh Surayya Ramadhani (2016) dengan skor reliabilitas sebesar 0,856 . Instrumen ini terdiri dari 27 item yang memiliki lima poin alternatif jawaban, yaitu sangat sesuai (SS), sesuai (S), kadang-kadang (K), tidak sesuai (TS), dan sangat tidak sesuai (STS).

Adapun pengukuran status identitas vokasional menggunakan instrumen Occupational Identity Scale (OIS) dari Melgosa (1987) yang mengembangkan teori James Marcia, yang terdiri dari empat dimensi dengan skor reliabilitas sebesar 0.69 untuk diffusion, 0.72 untuk foreclosure, 0.85 untuk moratorium, dan 0.87 untuk achievement. Instrumen ini terdiri dari satu domain khusus, yaitu Pekerjaan dan 28 item berdasarkan dari 4 dimensi yang memiliki lima poin alternatif jawaban, yaitu sangat sesuai (SS), sesuai (S), cukup sesuai (CS), tidak sesuai (TS), dan sangat tidak sesuai (STS). Teknik analisis yang digunakan adalah analisis regresi ganda dan Moderated Regression Analysis (MRA) dengan program Statistical Package for Social Sciences (SPSS) versi 25.0 dan Microsoft Excel 2010.

\section{HASIL DAN PEMBAHASAN}

Pada bagian ini, dipaparkan analisis dari data yang diperoleh 227 responden berusia 18-22 tahun yang merupakan mahasiswa Bidikmisi UPI tingkat satu, dua, tiga dan empat. Hasil analisis data terdiri dari gambaran karakteristik responden dan pembahasan hasil statistik. Gambaran karakteristik responden yang diketahui antara lain jenis kelamin serta tingkat mahasiswa. Data tersebut dapat dilihat pada Tabel 1.

Tabel 1. Data Demografis Responden

\begin{tabular}{lcc}
\hline Karakteristik & Frekuensi & Persentase \\
\hline Jenis Kelamin & & \\
Perempuan & 188 & $83 \%$ \\
Laki-laki & 39 & $17 \%$ \\
\hline Tingkat Mahasiswa & & \\
Empat & 59 & $26 \%$ \\
Tiga & 80 & $35 \%$ \\
Dua & 37 & $16 \%$ \\
Satu & 51 & $23 \%$ \\
\hline Jumlah Total & 227 & $100 \%$ \\
\hline
\end{tabular}




\begin{tabular}{lcc} 
Tabel 2. Gambaran umum perilaku Prokrastinasi \\
Akademik, Takut akan Kegagalan, \\
Identitas $\begin{array}{c}\text { Vokasional } \\
\text { Mahasiswa }\end{array}$ & $\begin{array}{c}\text { Status } \\
\text { Bidikmisi }\end{array}$ \\
Universitas Pendidikan Indonesia & & \\
\hline Kategori & $\mathrm{N}$ & $\%$ \\
\hline Prokrastinasi akademik & 34 & 15 \\
$\quad$ Tinggi & 163 & 72 \\
$\quad$ Sedang & 30 & 13 \\
Rendah & & \\
Takut akan kegagalan & 41 & 18 \\
Tinggi & 156 & 69 \\
Sedang & 30 & 13 \\
$\quad$ Rendah & & \\
Status identitas vokasional & 84 & 37 \\
$\quad$ Achievement & 136 & 60 \\
Moratorium & 2 & 1 \\
Foreclosure & 5 & 2 \\
Diffusion & & \\
\hline
\end{tabular}

Tabel 2 menunjukkan bahwa mahasiswa Bidikmisi Universitas Pendidikan Indonesia secara dominan memiliki prokrastinasi akademik yang sedang dengan jumlah 163 orang atau sebesar $72 \%$ dan secara dominan memiliki takut akan kegagalan yang sedang dengan jumlah 156 orang atau sebesar 69\%, Dari hasil data tersebut, dapat diketahui bahwa mahasiswa Bidikmisi tingkat satu sampai empat di Universitas Pendidikan Indonesia memiliki status identitas vokasional terbanyak berada pada kategori Moratorium sejumlah 136 mahasiswa (60\%), dengan total 84 mahasiswa sudah mencapai status identitas vokasional Achievement dan selebihnya masih berada dalam kategori status identitas vokasional Foreclosure dan Diffusion.

\section{Gambaran Umum Prokrastinasi Akademik}

Prokrastinasi akademik terjadi ketika tugas-tugas formal yang berhubungan dengan lingkup akademik ditunda pada awal dan atau saat penyelesaian tugas, saat well-being rendah, dan stres (Ferrari dkk., 1995; McCloskey, 2011). Temuan yang didapat dari penelitian ini menunjukkan bahwa responden cenderung tersebar pada setiap kategori perilaku prokrastinasi akademik, dengan persentase tertinggi terdapat dalam kategori prokrastinasi akademik sedang. Penyebab terjadinya hal tersebut diduga akibat responden dalam penelitian ini merupakan mahasiswa Bidikmisi yang memiliki rasa takut akan kegagalan karena berbagai tuntutan di perguruan tinggi, sehingga dapat pula memicu terjadinya stres. Hal ini sejalan dengan sebuah penelitian yang menyebutkan bahwa faktor internal pertama yang paling berkontribusi terhadap prokrastinasi pada mahasiswa adalah takut akan kegagalan, yaitu sebesar $6 \%$ hingga 14\% (Solomon \& Rothblum, 1984).

Semakin mahasiswa merasa takut akan kegagalan, semakin besar pula tendensi yang diperlihatkan untuk melakukan prokrastinasi akademik (Akmal dkk., 2017). Takut akan kegagalan dapat menjadi faktor terjadinya prokrastinasi akademik karena perasaan takut akan kegagalan mengarahkan individu untuk melindungi diri dari kemungkinan mengalami kegagalan, yaitu dengan cara menghindari tugas. Ketakukan mahasiswa akan dinilai buruk dan dikritik oleh orang lain membuat mereka melakukan prokrastinasi sebagai strategi untuk mengatasi takut akan kegagalan yang dirasakannya (Solomon \& Rothblum, 1984; Burka \& Yuen, 2008). Selain itu, prokrastinasi juga dianggap sebagai salah satu cara yang digunakan untuk mengatasi stres dalam menghadapi berbagai tuntutan (Pickhardt, 2009).

\section{Gambaran Umum Takut Akan Kegagalan}

Takut akan kegagalan merupakan dorongan untuk menghindari konsekuensi-konsekuensi yang tidak diinginkan (Conroy dkk., 2007). Takut akan kegagalan bisa muncul dari konsekuensi negatif yang dirasa mengancam individu karena pengalaman gagalnya (Atkinson, 1957). Temuan yang didapat dari penelitian ini menunjukkan bahwa responden cenderung tersebar pada setiap kategori takut akan kegagalan, dengan persentase tertinggi terdapat dalam kategori takut akan kegagalan sedang. Penyebab 
terjadinya hal tersebut diduga akibat responden dalam penelitian ini merupakan mahasiswa Bidikmisi yang memiliki tuntutan lulus tidak lebih dari empat tahun, mahasiswa penerima Bidikmisi yang tidak lulus tepat waktu selama empat tahun selanjutnya akan membayar uang kuliah tunggal (UKT) secara pribadi, tidak lagi ditanggung oleh pemerintah (Panduan Bidikmisi, 2018). Tuntutan tersebut dapat memunculkan keyakinan bahwa kegagalan akan membuat orang lain menghinanya dan kemudian memunculkan rasa malu dalam dirinya yang dipicu oleh negative self-talk dan perfeksionisme yang memberi tekanan dalam diri individu (Sagar \& Lavalle, 2010), takut kehilangan suatu kesempatan yang akan dijalaninya kemudian hari (Conroy, 2003; Sagar dkk., 2011), tidak dapat mengontrol performasinya dengan baik (Conroy dkk., 2002; Sagar dkk., 2011), takut membuat nilai individu menurun di lingkungan sosialnya dan membuatnya tidak memiliki pengaruh (Tsai \& Chen, 2009), serta ketakutan akan mengecewakan berkenaan dengan anggapan bahwa orang yang penting baginya akan menolak individu dan tidak lagi memberikan afeksi setelah individu mengalami kegagalan (Conroy dkk., 2002).

Hasil penelitian ini juga sejalan dengan penelitian dari Januar (2016) yang menunjukkan bahwa sebagian besar mahasiswa Departemen Psikologi UPI (73,23\%) mengalami ketakutan akan kegagalan dalam kategori sedang. Dengan kata lain, responden menganggap bahwa kegagalan terjadi bukan hanya karena tidak terwujudnya suatu harapan, usaha yang tidak cukup serta munculnya emosi negatif pada diri sendiri dan orang lain, melainkan ketakutan akan kegagalan merupakan motivasi bagi seseorang untuk meraih prestasi.

\section{Gambaran Umum Status Identitas Vokasional}

Hasil data Status Identitas Vokasional pada penelitian ini menunjukkan bahwa mahasiswa Bidikmisi paling banyak berada pada status identitas vokasional moratorium, yang berarti banyak dari mahasiswa Bidikmisi memiliki tingkat eksplorasi pekerjaannya tinggi, tetapi tingkat komitmennya rendah. Hal tersebut sejalan dengan penelitian yang mengatakan bahwa pengetahuan yang diperoleh melalui eksplorasi terhadap berbagai kemungkinan peran terjadi pada masa remaja atau masa kehidupan di kampus, yaitu pada rentang usia awal 20 tahun (Pychyl, 2008).

Responden dengan tingkat eksplorasi yang tinggi menunjukkan bahwa dimensi-dimensi dalam aspek pembentukan identitas, yaitu eksplorasi, dilakukan dengan baik. Beberapa diantaranya adalah menunjukkan adanya kedalaman pengetahuan, adanya aktivitas terarah dalam mengumpulkan informasi, dapat mempertimbangkan alternatif identitas lain yang potensial, menunjukkan emosi yang positif dalam menggali informasi dan membentuk identitasnya, dan adanya keinginan untuk membuat keputusan secara dini (Marcia \& Archer, 1993). Sejalan dengan penelitian sebelumnya, tingkatan eksplorasi yang tinggi menunjukkan bahwa responden mengumpulkan informasi tentang pilihan saat ini yang dimaksudkan untuk dijadikan panduan dalam mengatur dan mengevaluasi pilihannya (Luyckx dkk., 2005), salah satunya dalam bidang vokasional.

Responden yang memiliki tingkatan komitmen yang rendah menunjukkan dimensi pembentukan identitas yang tidak begitu menonjol, seperti kedalaman pengetahuan terkait pengambilan keputusan yang kurang, kurangnya aktivitas untuk mengimplementasikan aspek identitas yang dipilih, kurang menunjukkan emosi yang positif saat menentukan pilihannya serta dalam mengimplementasikan keputusannya, kurang melakukan identifikasi dengan orang-orang penting, kurangnya proyeksi terhadap masa depan, dan kurangnya daya tahan terhadap gangguan (Waterman, 1993). Rendahnya aspek komitmen dapat membuat individu kebingungan dalam menetapkan status identitasnya berdasarkan komitmen yang harus diputuskannya, bahkan individu tersebut tidak tertarik dalam membuat komitmen (Kroger, 2008). Sejalan pula dengan penelitian sebelumnya, tingkatan komitmen yang rendah menunjukkan tidak adanya proses identifikasi terhadap pilihan yang telah diputuskan (Luyckx dkk., 2005). 


\section{Hasil Moderasi Status Identitas Vokasional Achievement}

Tabel 3. Hasil Summary

\begin{tabular}{|c|c|c|c|}
\hline Model & $\begin{array}{l}\text { R } \\
\text { Kuadrat }\end{array}$ & $\begin{array}{l}\text { Adjusted } \\
\text { R } \\
\text { Square }\end{array}$ & $\begin{array}{l}\text { Std. Error } \\
\text { of the } \\
\text { Estimate }\end{array}$ \\
\hline 1 & 0,160 & 0,157 & 14,10967 \\
\hline 2 & 0,178 & 0,171 & 13,98745 \\
\hline 3 & 0,204 & 0,194 & 13,79486 \\
\hline
\end{tabular}

Berdasarkan Tabel 3, dapat dilihat bahwa nilai R kuadrat pada model 1 adalah sebesar 0,160, yang berarti bahwa rasa takut akan kegagalan memberikan kontribusi sebesar $16 \%$ pada perilaku prokrastinasi akademik pada mahasiswa Bidikmisi Universitas Pendidikan Indonesia. Artinya, masih terdapat $84 \%$ variabel independen lain yang dapat memengaruhi prokrastinasi akademik. Pada model 2, terdapat hasil bahwa status identitas vokasional Achievement memiliki pengaruh terhadap perilaku prokrastinasi akademik mahasiswa Bidikmisi Universitas Pendidikan Indonesia sebesar 0,178 atau 17,8\%, yang berarti terdapat $82,2 \%$ faktor lainnya yang dapat memengaruhi. Adapun pada model 3 , terdapat hasil nilai $\mathrm{R}$ kuadrat menunjukkan angka 0,204. Artinya, ketika Status Identitas Vokasional Achievement berinteraksi dengan takut akan kegagalan, akan memberikan pengaruh sebesar $20.4 \%$ terhadap perilaku prokrastinasi akademik mahasiswa Bidikmisi Universitas Pendidikan Indonesia.

Tabel 4. Coefficient tiap model persamaan (Status Identitas Vokasional Achievement)

\begin{tabular}{llrrl}
\hline \multicolumn{1}{c}{ Model } & \multicolumn{1}{c}{ B } & \multicolumn{1}{c}{ T } & \multicolumn{1}{c}{ Sig. } \\
\hline 1. & (Constant) & 42,308 & 9,794 & 0,000 \\
Takut akan Kegagalan & 0,461 & 6,553 & 0,000 \\
2. (Constant) & 54,267 & 7,896 & 0,000 \\
& Takut akan Kegagalan & 0,451 & 6,451 & 0,000 \\
Achievement & $-3,169$ & $-2,225$ & 0,027 \\
3. (Constant) & 113,930 & 4,932 & 0,000 \\
Takut akan Kegagalan & $-0,523$ & $-1,425$ & $-0,156$ \\
Achievement & $-19,252$ & $-3,147$ & 0,002 \\
Takut akan Kegagalan* Achievement & 0,263 & 2,702 & 0,007 \\
\hline
\end{tabular}

Berdasarkan Tabel 4, pada model persamaan 1 hasil menunjukkan bahwa takut akan kegagalan memiliki pengaruh terhadap perilaku prokrastinasi akademik mahasiswa Bidikmisi Universitas Pendidikan Indonesia secara signifikan (sig. $<0,05$ ). Takut akan kegagalan pada mahasiswa Bidikmisi Universitas Pendidikan Indonesia memiliki pengaruh positif terhadap perilaku prokrastinasi akademik. Jika mahasiswa memiliki takut akan kegagalan yang tinggi, ia akan menunjukkan perilaku prokrastinasi akademik yang tinggi pula. Pernyataan tersebut berdasarkan nilai koefisien takut akan kegagalan (b1), yang menunjukkan tanda positif.

Pada model persamaan 2, setelah dilakukan analisis regresi berganda, hasil takut akan kegagalan dan status identitas vokasional achievement memiliki koefisien yang signifikan $($ sig. $<0,05)$ dalam memengaruhi prokrastinasi akademik mahasiswa Universitas Pendidikan Indonesia.

Jika mahasiswa tidak memiliki takut akan kegagalan dan status identitas achievement, perilaku prokrastinasi akademik pada mahasiswa memiliki nilai sebesar 54,267. Sifat pengaruh status identitas vokasional achievement terhadap perilaku prokrastinasi akademik mahasiswa Bidikmisi Universitas Pendidikan Indonesia adalah negatif, yaitu jika mahasiswa memiliki status identitas vokasional achievement yang tinggi, mahasiswa akan memiliki perilaku prokrastinasi akademik yang rendah.

Pada model persamaan 3, data menunjukkan bahwa setelah status identitas vokasional achievement terlibat dalam pengaruh takut akan kegagalan terhadap prokrastinasi akademik, status identitas 
vokasional achievement akan memoderasi pengaruh takut akan kegagalan terhadap perilaku prokrastinasi akademik secara signifikan (sig. < 0,05). Variabel moderator merupakan variabel yang dapat mengintervensi suatu hubungan atau pengaruh dari variabel independen terhadap variabel dependen dengan memperkuat atau memperlemah hubungan atau pengaruh variabel independen terhadap variabel dependen (Jose, 2013; Hayes, 2013; Sugiono, 2004).

Merujuk Sugiono (2004), dapat ditinjau bahwa karakteristik yang ditunjukkan pada hasil penelitian ini, yakni koefisien b2 dan koefisien b3 pada model persamaan (3), bernilai signifikan $(<0.05)$. Maka, dapat diambil kesimpulan bahwa variabel status identitas vokasional achievement merupakan variabel quasi moderator pada pengaruh takut akan kegagalan terhadap prokrastinasi akademik pada mahasiswa Bidikmisi Universitas Pendidikan Indonesia. Variabel quasi moderator (moderasi semu) adalah variabel yang dapat menjadi variabel moderator dan variabel independen, apabila hasil pengujian secara parsial maupun interaksi menunjukkan hasil yang sama-sama signifikan (Putra dkk., 2015).

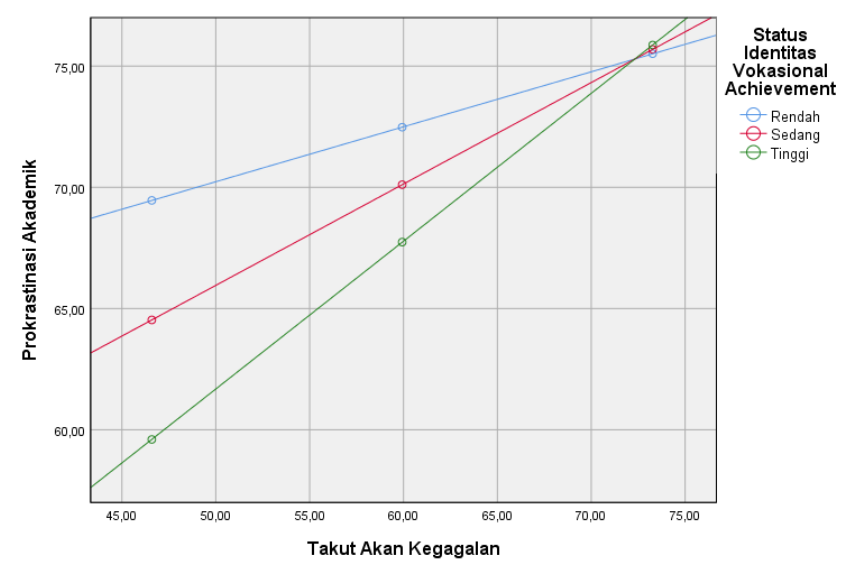

\section{Gambar 1. Grafik Moderasi Status Achievement}

Berdasarkan Gambar 1, pada grafik moderasi status identitas vokasional achievement, dapat dilihat bahwa garis-garis dalam grafik berpotongan di bagian atas. Artinya, status identitas vokasional achievement signifikan atau mampu memoderasi takut akan kegagalan sebagai prediktor prokrastinasi akademik (Jose, 2013). Selain itu, dapat dilihat bahwa takut akan kegagalan memengaruhi prokrastinasi akademik pada mahasiswa dengan status identitas vokasional achievement yang sedang dan tinggi. Adapun pada mahasiswa dengan status identitas vokasional achievement yang rendah, takut akan kegagalan tidak memengaruhi prokrastinasi akademik karena grafiknya menunjukkan pergerakan yang semakin mendatar serta nilai prokrastinasi akademik yang tetap tinggi di atas 65. Oleh karena itu, dapat disimpulkan semakin tinggi takut akan kegagalan, maka akan semakin tinggi prokrastinasi yang hanya terjadi pada mahasiswa achievement sedang dan tinggi. Sebaliknya, takut akan kegagalan yang dirasakan mahasiswa dengan achievement rendah tidak memengaruhi prokrastinasi. Hal ini disebabkan oleh tingkat prokrastinasi mahasiswa tetap akan bernilai tinggi terlepas dari tingkat takut akan kegagalannya.

Berdasarkan hasil yang telah didapatkan dari analisis data, status identitas vokasional achievement berperan sebagai quasi moderator (moderator semu) atau variabel yang memoderasi pengaruh takut akan kegagalan terhadap prokrastinasi akademik pada mahasiswa Bidikmisi Universitas Pendidikan Indonesia, juga memiliki peran sebagai variabel prediktor/independen. Dapat dikatakan, sebagian mahasiswa Bidikmisi Universitas Pendidikan Indonesia memiliki perilaku prokrastinasi akademik yang dipengaruhi oleh takut akan kegagalan. Jika mahasiswa memiliki takut akan kegagalan yang tinggi, ia akan memiliki perilaku prokrastinasi akademik yang tinggi pula. Hasil tersebut didukung oleh hasil penelitian Solomon \& Rothblum (1984) yang mengatakan bahwa ketakutan akan kegagalan merupakan salah satu faktor terbesar individu melakukan perilaku prokrastinasi akademik. Semakin mahasiswa merasa takut akan kegagalan, semakin besar pula tendensi yang diperlihatkan untuk melakukan prokrastinasi akademik (Akmal dkk., 2017).

Pada penelitian ini, perilaku prokrastinasi akademik mahasiswa dapat berubah apabila mahasiswa telah mencapai status identitas vokasional achievement. Semakin tinggi nilai status identitas vokasional 
achievement, tingkat takut akan kegagalan akan menurun sehingga nilai prokrastinasi akademik pada mahasiswa Bidikmisi dapat menurun pula. Didukung oleh penelitian Ramadhani (2016) yang menyatakan bahwa mahasiswa dengan status identitas vokasional achievement melakukan prokrastinasi akademik dengan tingkatan yang rendah.

Hal tersebut sesuai dengan karakteristik mahasiswa dengan status identitas vokasional achievement yang telah melakukan eksplorasi dan telah menetapkan komitmen terhadap berbagai pilihan pekerjaan yang memungkinkan (Marcia dkk, 1993), bermotivasi tinggi dan percaya diri (Dariyo, 2004; Steinberg, 2017), memiliki peluang lebih besar untuk memiliki aktualisasi diri yang lebih baik daripada status identitas lainnya (Sunanto dkk., 2013), serta memiliki kontrol internal sehingga memungkinkan mereka tidak prokrastinasi sebagaimana dijelaskan dalam hasil penelitian Purnomo dan Izzati (2013). Penelitian tersebut menyatakan bahwa semakin tinggi nilai internal locus of control seseorang, maka semakin rendah tingkat prokrastinasi akademiknya.

Oleh karena itu, hal tersebut memungkinkan mahasiswa dengan status identitas vokasional achievement mengubah rasa takut akan kegagalannya menjadi sebuah motivasi sebagaimana pernyataan Setyadi dan Mastuti (2014) bahwa ketakutan akan kegagalan dapat memotivasi mahasiswa untuk meraih keberhasilan, sehingga dapat mengurangi perilaku prokrastinasi akademik yang dialami mahasiswa Bidikmisi.

\section{Hasil Moderasi Status Identitas Vokasional Moratorium}

Tabel 5. Hasil Summary

\begin{tabular}{lrrr}
\hline Model & R Kuadrat & Adj R Square & $\begin{array}{l}\text { Std. Error of } \\
\text { the Estimate }\end{array}$ \\
\hline 1 & 0,160 & 0,157 & 14,10967 \\
2 & 0,162 & 0,154 & 14,12726 \\
3 & 0,169 & 0,158 & 14,09697 \\
\hline
\end{tabular}

Berdasarkan Tabel 5, dapat dilihat bahwa nilai R kuadrat pada model 1 adalah sebesar 0,160, yang berarti bahwa rasa takut akan kegagalan memberikan kontribusi sebesar $16 \%$ pada perilaku prokrastinasi akademik pada mahasiswa Bidikmisi Universitas Pendidikan Indonesia. Artinya, masih terdapat $84 \%$ variabel independen lain yang dapat mempengaruhi prokrastinasi akademik. Pada model 2, terdapat hasil bahwa status identitas vokasional moratorium memiliki pengaruh terhadap perilaku prokrastinasi akademik mahasiswa Bidikmisi Universitas Pendidikan Indonesia sebesar 0,162 atau $16,2 \%$. Hal ini mengindikasikan bahwa terdapat $83,8 \%$ faktor lainnya yang dapat mempengaruhi prokrastinasi akademik. Adapun pada model 3, hasil nilai $\mathrm{R}$ kuadrat menunjukkan angka 0,169, yang berarti ketika status identitas vokasional Moratoriummoratorium berinteraksi dengan takut akan kegagalan, sttaus identitas vokasional akan memberikan pengaruh sebesar 16,9\% terhadap perilaku prokrastinasi akademik mahasiswa Universitas Pendidikan Indonesia.

Tabel 6. Coefficient tiap model persamaan (Status Identitas Vokasional Moratorium)

\begin{tabular}{llrcc} 
& Model & \multicolumn{1}{c}{ B } & T & Sig. \\
\hline 1. & (Constant) & 42,308 & 9,794 & 0,000 \\
& Takut akan & 0,461 & 6,553 & 0,000 \\
& Kegagalan & & & \\
2. & (Constant) & 38,675 & 5,541 & 0,000 \\
& Takut akan & 0,451 & 6,238 & 0,000 \\
& Kegagalan & & & \\
& Moratorium & $-1,131$ & 0,663 & 0,508 \\
\hline
\end{tabular}




\begin{tabular}{lrrr}
\hline 3. (Constant) & 76,224 & 2,753 & 0,006 \\
& & & \\
Takut akan & $-0,179$ & $-0,393$ & 0,695 \\
Kegagalan & & & \\
Moratorium & $-8,729$ & $-1,206$ & 0,229 \\
Takut akan & 0,165 & 1,401 & 0,163 \\
Kegagalan* & & & \\
Moratorium & & & \\
\hline
\end{tabular}

Berdasarkan Tabel 6, pada model persamaan 2, hasil data menunjukkan bahwa tidak terdapat perubahan signifikansi (sig. $<0,05)$ takut akan kegagalan terhadap prokrastinasi setelah dilakukan analisis regresi berganda dengan takut akan kegagalan dan status identitas vokasional moratorium sebagai variabel independen/prediktor. Namun, dapat dilihat bahwa status identitas vokasional moratorium tidak memiliki pengaruh yang signifikan (sig. $>0,05$ ) terhadap perilaku prokrastinasi akademik mahasiswa Bidikmisi Universitas Pendidikan Indonesia. Jika mahasiswa tidak memiliki takut akan kegagalan dan status identitas moratorium, maka perilaku prokrastinasi akademik pada mahasiswa memiliki nilai sebesar 38,675.

Pada model persamaan 3, data menunjukkan bahwa setelah status identitas vokasional moratorium terlibat dalam pengaruh takut akan kegagalan terhadap prokrastinasi akademik, status identitas vokasional moratorium akan memoderasi pengaruh takut akan kegagalan terhadap perilaku prokrastinasi akademik secara tidak signifikan (sig. $>0,05$ ). Variabel moderator merupakan variabel yang dapat mengintervensi suatu hubungan atau pengaruh dari variabel independen terhadap variabel dependen dengan memperkuat atau memperlemah hubungan atau pengaruh variabel independen terhadap variabel dependen (Hayes, 2013; Jose, 2013; Sugiono, 2004).

Merujuk Sugiono (2004), dapat ditinjau karakteristik yang ditunjukkan pada hasil penelitian ini adalah koefisien b2 dan koefisien b3 pada model persamaan (3) adalah tidak signifikan $(>0,05)$. Maka, dapat diambil kesimpulan bahwa variabel status identitas vokasional moratorium tidak menjadi variabel prediktor maupun variabel moderator pada pengaruh takut akan kegagalan terhadap prokrastinasi akademik pada mahasiswa Bidikmisi Universitas Pendidikan Indonesia.

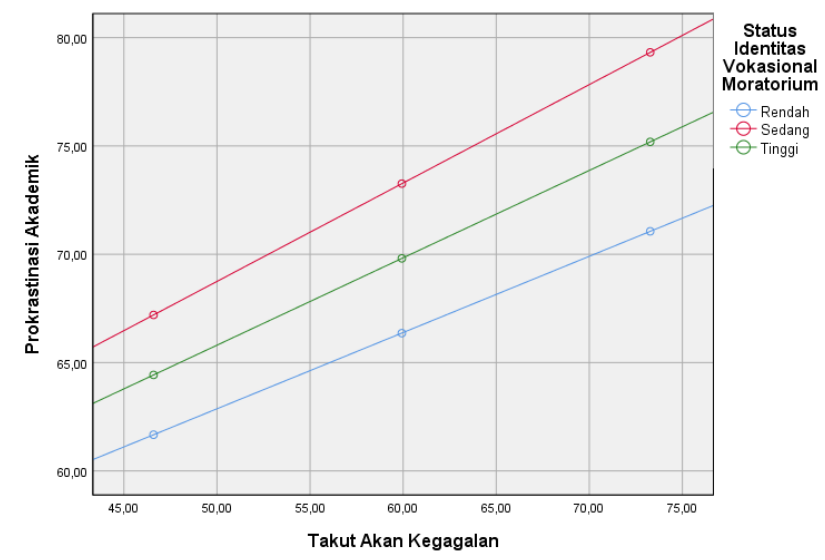

\section{Gambar 2. Grafik Moderasi Status Moratorium}

Berdasarkan Gambar 2 dapat dilihat bahwa garis-garis dalam grafik sejajar dan tidak berpotongan. Hal ini berarti dapat disimpulkan bahwa status identitas vokasional moratorium tidak signifikan atau tidak mampu menjadi prediktor maupun memoderasi takut akan kegagalan sebagai prediktor prokrastinasi akademik (Jose, 2013).

Berdasarkan hasil yang telah didapatkan dari analisis data, status identitas vokasional moratorium tidak menjadi variabel prediktor maupun variabel moderator pada pengaruh Takut akan Kegagalan terhadap Prokrastinasi Akademik pada Mahasiswa Bidikmisi Universitas Pendidikan Indonesia. 
Hal tersebut sesuai dengan karakteristik mahasiswa dengan status identitas vokasional moratorium yang telah melakukan eksplorasi pekerjaan dengan cukup baik, namun tidak didukung dengan adanya komitmen atau keteguhan dalam menentukan pilihan pekerjaan (Marcia dkk, 1993). Responden yang memiliki tingkatan komitmen yang rendah menunjukkan bahwa dimensi-dimensi dalam aspek pembentukan identitas yaitu komitmen tidak begitu menonjol, yaitu kedalaman pengetahuan terkait pengambilan keputusan yang kurang, kurangnya aktivitas untuk mengimplementasikan aspek identitas yang dipilih, kurang menunjukkan emosi yang positif saat menentukan pilihannya serta dalam mengimplementasikan keputusannya, kurang melakukan identifikasi dengan orang-orang penting, kurangnya proyeksi terhadap masa depan, dan kurangnya daya tahan terhadap gangguan (Waterman, 1993).

Rendahnya aspek komitmen dapat membuat individu kebingungan dalam menetapkan status identitasnya berdasarkan komitmen yang harus diputuskannya, bahkan individu tersebut tidak tertarik dalam membuat komitmen (Kroger, 2008). Sejalan pula dengan penelitian sebelumnya, tingkatan komitmen yang rendah menunjukkan tidak adanya proses identifikasi terhadap pilihan yang telah diputuskan (Luyckx dkk., 2005). Sebuah penelitian juga menunjukkan bahwa individu yang berada pada status identitas vokasional moratorium cenderung merasa cemas dan kurang percaya diri (Dariyo, 2004), sehingga dapat memungkinkan hal-hal yang telah dijelaskan tersebut menjadikan status identitas vokasional moratorium ini tidak memengaruhi tingkatan takut akan kegagalan maupun prokrastinasi akademik.

\section{Hasil Moderasi Status Identitas Vokasional Foreclosure}

Tabel 7. Hasil Summary

\begin{tabular}{lrrr}
\hline Model & $\begin{array}{l}\text { R } \\
\text { Kuadrat }\end{array}$ & $\begin{array}{l}\text { Adj R } \\
\text { Square }\end{array}$ & $\begin{array}{l}\text { Std. Error } \\
\text { of the } \\
\text { Estimate }\end{array}$ \\
\hline 1 & 0,160 & 0,157 & 14,10967 \\
2 & 0,163 & 0,156 & 14,11816 \\
3 & 0,195 & 0,184 & 13,88048 \\
\hline
\end{tabular}

Berdasarkan Tabel 7, dapat dilihat bahwa nilai R kuadrat pada model 1 adalah sebesar 0,160, yang berarti bahwa rasa takut akan kegagalan memberikan kontribusi sebesar 16\% pada perilaku prokrastinasi akademik pada mahasiswa Bidikmisi Universitas Pendidikan Indonesia. Artinya, masih terdapat 84\% variabel independen lain yang dapat memengaruhi prokrastinasi akademik. Pada model 2 terdapat hasil bahwa status identitas vokasional foreclosure memiliki pengaruh terhadap perilaku prokrastinasi akademik mahasiswa Bidikmisi Universitas Pendidikan Indonesia sebesar 0,163 atau 16,3\%, yang berarti terdapat $83,7 \%$ faktor lainnya yang dapat memengaruhi. Sedangkan pada model 3 , terdapat hasil nilai $\mathrm{R}$ kuadrat menunjukkan angka 0,195 yang berarti ketika status identitas vokasional foreclosure berinteraksi dengan takut akan kegagalan, akan memberikan pengaruh sebesar 19,5\% terhadap perilaku prokrastinasi akademik mahasiswa Bidikmisi Universitas Pendidikan Indonesia.

Tabel 8. Coefficient tiap model persamaan (Status Identitas Vokasional Foreclosure)

\begin{tabular}{llrrc}
\hline & Model & \multicolumn{1}{c}{ B } & \multicolumn{1}{c}{ T } & Sig. \\
\hline 1. & (Constant) & 42,308 & 9,794 & 0,000 \\
& Takut akan & 0,461 & 6,553 & 0,000 \\
& Kegagalan & & & \\
2. & (Constant) & 45,590 & 7,883 & 0,000 \\
& Takut akan & 0,463 & 6,577 & 0,000 \\
& Kegagalan & & & \\
\hline
\end{tabular}




\begin{tabular}{lrrr}
\hline Foreclosure & 1,209 & $-0,854$ & 0,394 \\
3. (Constant) & 90,841 & 5,562 & 0,000 \\
& & & \\
Takut akan & 0,275 & $-1,060$ & - \\
Kegagalan & & & 0,290 \\
Foreclosure & 16,835 & $-3,080$ & 0,002 \\
Takut akan & 0,254 & 2,956 & 0,003 \\
Kegagalan* & & & \\
Foreclosure & & & \\
\hline
\end{tabular}

Berdasarkan Tabel 8, pada model persamaan 2, hasil data menunjukkan bahwa tidak terdapat perubahan signifikansi (sig. $<0,05)$ takut akan kegagalan terhadap prokrastinasi setelah dilakukan analisis regresi berganda dengan takut akan kegagalan dan status identitas vokasional foreclosure sebagai variabel independen/prediktor. Namun, dapat dilihat bahwa status identitas vokasional foreclosure tidak memiliki pengaruh yang signifikan (sig. $>0,05)$ terhadap perilaku prokrastinasi akademik mahasiswa Bidikmisi Universitas Pendidikan Indonesia.

Jika mahasiswa tidak memiliki takut akan kegagalan dan status identitas foreclosure, perilaku prokrastinasi akademik pada mahasiswa memiliki nilai sebesar 45,590. Sifat pengaruh status identitas vokasional foreclosure terhadap perilaku prokrastinasi akademik mahasiswa Bidikmisi Universitas Pendidikan Indonesia bersifat positif, yakni apabila mahasiswa memiliki status identitas vokasional foreclosure yang tinggi, maka mahasiswa akan memiliki perilaku prokrastinasi akademik yang tinggi pula.

Pada model persamaan 3, data menunjukkan bahwa setelah status identitas vokasional foreclosure terlibat dalam pengaruh takut akan kegagalan terhadap prokrastinasi akademik, status identitas vokasional foreclosure akan memoderasi pengaruh takut akan kegagalan terhadap perilaku prokrastinasi akademik secara signifikan (sig. $>0,05$ ). Variabel moderator merupakan variabel yang dapat mengintervensi suatu hubungan atau pengaruh dari variabel independen terhadap variabel dependen dengan memperkuat atau memperlemah hubungan atau pengaruh variabel independen terhadap variabel dependen (Jose, 2013; Hayes, 2013; Sugiono, 2004).

Merujuk Sugiono (2004), koefisien b2 pada model persamaan (2) adalah tidak signifikan ( $>0.05)$. Lalu, pada model persamaan (3), koefisien b3 bernilai signifikan $(<0,05)$. Dapat diambil kesimpulan bahwa variabel status identitas vokasional foreclosure merupakan variabel-variabel pure moderator pada pengaruh takut akan kegagalan terhadap prokrastinasi akademik pada mahasiswa Bidikmisi Universitas Pendidikan Indonesia. Variabel pure moderator (moderasi murni) adalah variabel yang dapat menjadi variabel moderator tanpa menjadi variabel independen, dan apabila hasil pengujian secara parsial tidak signifikan dan pengujian secara interaksi menunjukan hasil yang signifikan (Putra dkk., 2015).

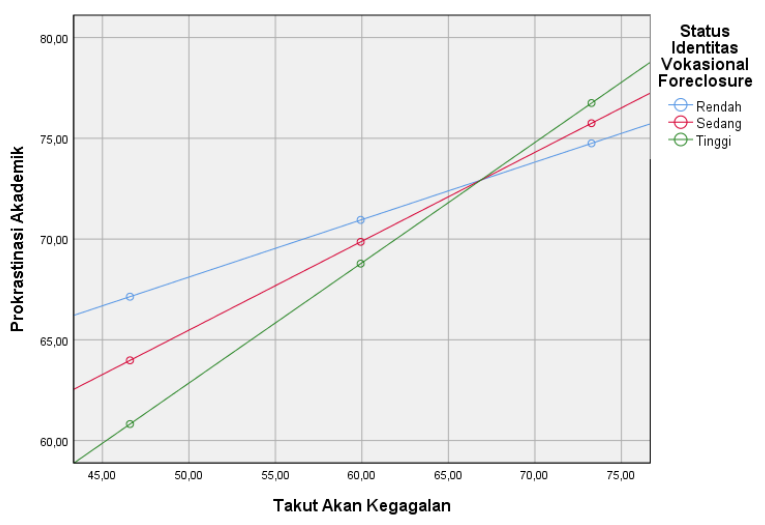

Gambar 3. Grafik Moderasi Foreclosure 
Berdasarkan Gambar 3 pada grafik moderasi status identitas vokasional foreclosure, dapat dilihat bahwa garis-garis dalam grafik berpotongan di bagian atas. Hal ini menggambarkan status identitas vokasional foreclosure yang bernilai signifikan atau mampu memoderasi takut akan kegagalan sebagai prediktor prokrastinasi akademik (Jose, 2013). Selain itu, dapat dilihat bahwa takut akan kegagalan memengaruhi prokrastinasi akademik pada mahasiswa dengan status identitas vokasional foreclosure yang sedang dan tinggi ditandai dengan rentang grafik lebih besar/panjang. Adapun pada mahasiswa dengan status identitas vokasional foreclosure yang rendah, rentang grafik lebih kecil atau semakin mendatar dan nilai prokrastinasi akademiknya tetap besar, yakni di atas 65. Dengan demikian, dapat disimpulkan semakin tinggi nilai status identitas vokasional foreclosure, maka akan menambah tingkat takut akan kegagalan yang dapat menaikkan pula nilai prokrastinasi akademik pada mahasiswa Bidikmisi.

Hal tersebut sesuai dengan karakteristik mahasiswa dengan status identitas vokasional foreclosure yang sudah terlebih dulu melakukan komitmen, tetapi belum melakukan eksplorasi dalam pekerjaannya (Marcia dkk, 1993), semakin lama individu mempertahankan identitas foreclosure, semakin besar pula perasaan malu dan perasaan bersalah yang disertai mempertanyakan posisinya (Kroger \& Marcia, 2011), pembentukan identitas diri foreclosure ditunjukkan dengan kemampuan eksplorasi yang rendah digambarkan dengan kurangnya pengetahuan mengenai tempat pendidikan, dan mengikuti keputusan dari sekitar (Asmawati dkk., 2013). Hasil penelitian ini didukung oleh penelitian sebelumnya yang menyatakan orang yang mempunyai identitas diri foreclosure seringkali cemas dan tidak percaya diri, serta memiliki kontrol eksternal (Dariyo, 2004) yang dapat menyebabkan remaja melakukan prokrastinasi. Hal ini disebabkan oleh semakin tinggi nilai external locus of control seseorang maka semakin tinggi pula nilai prokrastinasi akademiknya (Purnomo dan Izzati, 2013). Maka dari itu, mahasiswa dengan status identitas vokasional foreclosure diperkirakan menjadikan rasa takut akan kegagalannya sebagai penguat dilakukannya prokrastinasi akademik

\section{Hasil Moderasi Status Identitas Vokasional Diffusion}

Tabel 9. Hasil Summary

\begin{tabular}{lrrr}
\hline Model & $\begin{array}{l}\text { R } \\
\text { Kuadrat }\end{array}$ & $\begin{array}{l}\text { Adj } \\
\text { R } \\
\text { Square }\end{array}$ & $\begin{array}{l}\text { Std. Error } \\
\text { of the } \\
\text { Estimate }\end{array}$ \\
\hline 1 & 0,160 & 0,157 & 14,10967 \\
2 & 0,207 & 0,200 & 13,73851 \\
3 & 0,210 & 0,200 & 13,74343 \\
\hline
\end{tabular}

Berdasarkan Tabel 9, dapat dilihat bahwa nilai R kuadrat pada model 1 adalah sebesar 0,160, yang berarti bahwa rasa takut akan kegagalan memberikan kontribusi sebesar $16 \%$ pada perilaku prokrastinasi akademik pada mahasiswa Bidikmisi Universitas Pendidikan Indonesia. Artinya, masih terdapat $84 \%$ variabel independen lain yang dapat memengaruhi prokrastinasi akademik. Pada model 2, terdapat hasil bahwa status identitas vokasional diffusion memiliki pengaruh terhadap perilaku prokrastinasi akademik mahasiswa Bidikmisi Universitas Pendidikan Indonesia sebesar 0,207 atau 20,7\%. Adapun pada model 3, terdapat hasil nilai $\mathrm{R}$ kuadrat menunjukkan angka 0,210. Hal ini mengindikasikan bahwa ketika status identitas vokasional diffusion berinteraksi dengan takut akan kegagalan, variabel tersebut akan memberikan pengaruh sebesar $21 \%$ terhadap perilaku prokrastinasi akademik mahasiswa Bidikmisi Universitas Pendidikan Indonesia.

Tabel 10. Coefficient tiap model persamaan (Status Identitas Vokasional Diffusion)

\begin{tabular}{ccccc}
\hline & Model & B & T & Sig. \\
\hline 1. & (Constant) & 42,308 & 9,794 & 0,000 \\
\hline
\end{tabular}




\begin{tabular}{|c|c|c|c|c|}
\hline & $\begin{array}{l}\text { Takut akan } \\
\text { Kegagalan }\end{array}$ & 0,461 & 6,553 & 0,000 \\
\hline \multirow[t]{3}{*}{2.} & (Constant) & 31,831 & 6,251 & 0,000 \\
\hline & $\begin{array}{l}\text { Takut akan } \\
\text { Kegagalan }\end{array}$ & 0,412 & 5,908 & 0,000 \\
\hline & Diffusion & 4,888 & 3,650 & 0,000 \\
\hline \multirow[t]{4}{*}{3.} & (Constant) & 44,736 & 2,987 & 0,003 \\
\hline & $\begin{array}{l}\text { Takut akan } \\
\text { Kegagalan }\end{array}$ & 0,190 & 0,756 & 0,451 \\
\hline & Diffusion & 0,351 & 0,068 & 0,946 \\
\hline & $\begin{array}{l}\text { Takut akan } \\
\text { Kegagalan* } \\
\text { Diffusion }\end{array}$ & 0,077 & 0,916 & 0,360 \\
\hline
\end{tabular}

Berdasarkan Tabel 10, setelah dilakukan analisis regresi berganda pada model persamaan 2, hasil takut akan kegagalan dan status identitas vokasional diffusion memiliki koefisien yang tetap signifikan (sig. $<0,05$ ) dalam memengaruhi prokrastinasi akademik mahasiswa Bidikmisi Universitas Pendidikan Indonesia. Data tersebut menunjukkan sifat interaksi variabel mediasi atau intervening, status identitas vokasional diffusion dapat berperan sebagai variabel mediator dalam pengaruh takut akan kegagalan terhadap prokrastinasi akademik mahasiswa Bidikmisi Universitas Pendidikan Indonesia. Berdasarkan acuan Baron \& Kenny (1986), sifat mediasi yang dimiliki oleh variabel status identitas vokasional diffusion adalah parsial mediation, dimana mediasi terjadi karena pengaruh variabel independen (x) terhadap variabel dependen (y) tetap signifikan karena adanya variabel lain (z). Dalam penelitian ini, variabel lain (z) yang dimaksud adalah status identitas vokasional diffusion.

Jika mahasiswa tidak memiliki takut akan kegagalan dan status identitas diffusion, perilaku prokrastinasi akademik pada mahasiswa memiliki nilai sebesar 31,831 . Sifat pengaruh status identitas vokasional diffusion terhadap perilaku prokrastinasi akademik mahasiswa Bidikmisi Universitas Pendidikan Indonesia adalah positif, yakni jika mahasiswa memiliki status identitas vokasional diffusion yang tinggi, mahasiswa akan memiliki perilaku prokrastinasi akademik yang tinggi pula.

Pada model persamaan 3, status identitas vokasional diffusion tidak secara signifikan memoderasi pengaruh takut akan kegagalan terhadap perilaku prokrastinasi akademik (sig. $>0,05$ ). Merujuk Sugiono (2004), dapat ditinjau karakteristik yang ditunjukkan pada hasil penelitian ini adalah koefisien b2 pada model persamaan $(2)$ adalah signifikan $(<0,05)$, lalu pada model persamaan (3) koefisien b2 tidak signifikan $(>0,05)$ dan koefisien b3 juga tidak signifikan $(>0,05)$. Maka dapat diambil kesimpulan bahwa variabel status identitas vokasional diffusion bukan variabel moderator melainkan variabel intervening atau variabel mediator pada pengaruh takut akan kegagalan terhadap prokrastinasi akademik pada mahasiswa Bidikmisi Universitas Pendidikan Indonesia, seperti dijelaskan pada model persamaan (2) sebelumnya. Variabel intervening adalah variabel yang secara teoritis memengaruhi hubungan antara variabel independen dengan dependen, sehingga variabel independen tidak langsung memengaruhi berubahnya variabel dependen (Sugiono, 2017). 


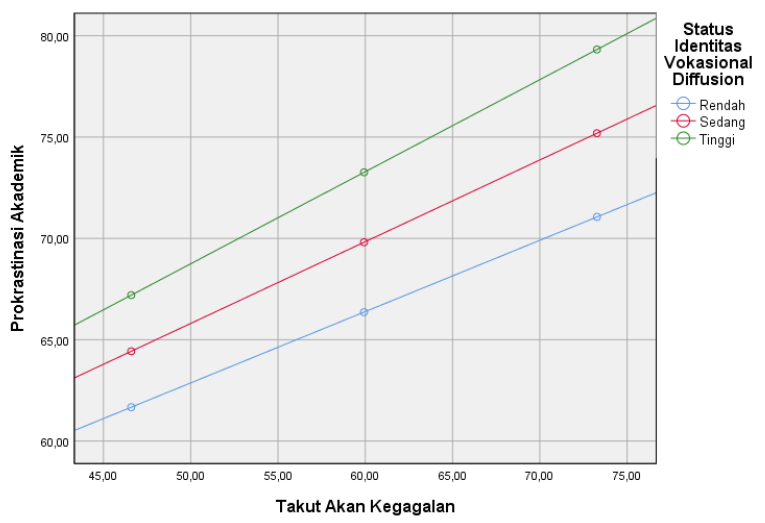

Gambar 4. Grafik Moderasi Status Diffusion

Berdasarkan Gambar 4 pada grafik moderasi status identitas vokasional diffusion, dapat dilihat bahwa garis-garis dalam grafik sejajar dan tidak berpotongan. Hal ini berarti status identitas vokasional diffusion tidak signifikan atau tidak mampu memoderasi takut akan kegagalan sebagai prediktor prokrastinasi akademik (Jose, 2013). Selain itu, adanya jarak yang sama antara satu garis dengan garisgaris lainnya mencerminkan pengaruh status identitas vokasional diffusion pada prokrastinasi akademik, yang menghasilkan bahwa garis status identitas vokasional diffusion tinggi menghasilkan tingkat prokrastinasi akademik tertinggi. Sehingga dapat disimpulkan semakin tinggi nilai status identitas vokasional diffusion maka akan meningkatkan perilaku prokrastinasi akademik pada mahasiswa Bidikmisi.

Berdasarkan hasil yang telah didapatkan dari analisis data, status identitas vokasional diffusion tidak berperan sebagai variabel moderator, melainkan variabel intervening atau prediktor pada pengaruh takut akan kegagalan terhadap prokrastinasi akademik pada mahasiswa Bidikmisi Universitas Pendidikan Indonesia. Semakin tinggi nilai status identitas vokasional diffusion, maka akan dapat menambah pula nilai prokrastinasi akademik pada mahasiswa Bidikmisi. Didukung oleh penelitian Ramadhani (2016) yang menyatakan bahwa mahasiswa dengan status identitas vokasional diffusion melakukan prokrastinasi akademik dengan tingkatan yang tinggi.

Hal tersebut sesuai dengan karakteristik mahasiswa dengan status identitas vokasional diffusion yang memiliki tingkatan komitmen dan eksplorasi berada dalam tingkatan yang rendah, individu tidak melakukan eksplorasi terhadap alternatif-alternatif pekerjaan yang ada dan belum mampu membuat komitmen (Marcia \& Archer, 1993), memiliki aktualisasi diri yang rendah (Sunanto dkk., 2013), memiliki konsep diri lambat, kemampuan kognitif tidak berfungsi baik, ragu-ragu, pasif, dan tidak inisiatif (Dariyo, 2004), serta cenderung memiliki masalah interpersonal (Steinberg, 2017) sehingga dapat memungkinkan individu ini untuk melakukan prokrastinasi begitupun dalam lingkup akademik

Terdapat beberapa keterbatasan dalam penelitian ini antara lain sebagai berikut:

1. Mahasiswa tingkat tiga yang mendominasi dalam penelitian ini membuat data penelitian kurang tersebar secara menyeluruh.

2. Penelitian ini masih terbatas hingga wilayah Universitas Pendidikan Indonesia saja.

\section{SIMPULAN}

Berdasarkan penelitian yang telah dilakukan, dapat disimpulkan bahwa takut akan kegagalan memiliki pengaruh yang signifikan terhadap perilaku prokrastinasi akademik pada mahasiswa Bidikmisi Universitas Pendidikan Indonesia. Status identitas vokasional achievement berperan sebagai quasi moderator, status identitas vokasional moratorium tidak memoderasi, status identitas vokasional foreclosure berperan sebagai pure moderator, dan status identitas vokasional diffusion berperan sebagai variabel intervening pada penelitian ini. Mahasiswa, khususnya yang memiliki tingkat prokrastinasi tinggi, disarankan untuk mengeksplorasi diri lebih dalam dan menetapkan komitmen agar dapat mencapai pembentukan identitas yang matang sehingga perilaku prokrastinasi dapat berkurang. Dengan demikian, 
sekalipun mengalami takut akan kegagalan maka hal tersebut dapat dijadikan motivasi untuk tidak menunda tugas-tugas akademik.

\section{DAFTAR PUSTAKA}

Akmal, Arlinkasari, \& Fitriani. (2017). Hope of Success and Fear of Failure Predicting Academic Procrastination Students Who Working on a Thesis. Jurnal Ilmu Pendidikan, Psikologi, Bimbingan dan Konseling, 7(1), Page $78-86$.

Amanda, V. (2019). Pengaruh Takut akan Kegagalan terhadap Prokrastinasi Menulis Skripsi yang dimoderasi Dukungan Sosial Teman Sebaya pada Mahasiswa Universitas Pendidikan Indonesia. S1 Thesis, Universitas Pendidikan Indonesia.

Asmawati, A. Z., Faizah, \& Lestari, S. (2013). Pembentukan Identitas Diri Foreclosure Pada Remaja Dalam Menempuh Pendidikan Di Pondok Pesantren. Jurnal Penelitian Universitas Brawijaya Malang, 1-15.

Athanas, E. (2007). Fear of failure, experience, and division as predictors of state anxiety in USFA EPEE Fencers. Electronic Theses and Dissertations. Georgia Southern University.

Atkinson, J. W. (1957). Motivational Determinants Of Risk-Taking Behavior. Psychological Review, 64 (6), 359-372.

Baron, R. M., \& Kenny, D. A. (1986). The Moderator-Mediator Variable Distinction In Social Psychological Research: Conceptual, Strategic, And Statistical Considerations. Journal Of Personality And Social Psychology, 51 (6), 1173-1182.

Burka, J. B., \& Yuen, L. M. (2008). Procrastination: Why you do it, what to do about it now. Cambridge: Da Capo Press.

Chen, L. H., Wu, C. H., Kee, Y. H., Lin, M. S., \& Shui, S. H. (2009): Fear Of Failure, 2 X 2 Achievement Goal And Self-Handicapping. An Examination Of The Hierarchical Model of Achievement Motivation In Physical Education. Contemporary Educational Psychology, 34 (4), 298-305.

Conroy, D. E., Coatsworth, J. D., \& Fifer, A. M. (2005). Testing Dynamic Relations Between Perceived Competence And Fear Of Failure In Young Athletes. Revue Eurepenne De Psychologie Appliquee, $55(2), 99-110$.

Conroy, D. E., Coatsworth, J. D., \& Kaye, M. P. (2007). Consistency Of Fear Of Failure Score Meanins Among 8 To 18 Year Old Female Athletes. Educational And Psychological Measurement, 67 (2), 300-310.

Conroy, D. E., Kaye, M. P., \& Fifer, A. M. (2007). Cognitive links between fear of failure and procrastination. Journal of Rational-Emotive \& Cognitive-Behavior Therapy, 25(4), 237-253

Conroy, D. E., Willow, J. P., \& Metzler, J. N., (2002). Multidimensional Fear Of Failure Measurement: The Performance Failure Appraisal Inventory. Journal Of Applied Sport Psychology, 2, 76-90.

Dariyo. (2004). Psikologi Perkembangan Remaja. Bogor Selatan: Ghalia Indonesia.

Djamarah, S. B. (2008). Rahasia Sukses Belajar. Jakarta: Rineka Cipta.

Elison, J., \& Partridge, J. A. (2012). Relationships between shame-coping, fear of failure, and perfectionism in college athletes. Journal of Sport Behavior, 35(1), 19-39.

Fauziah, Hana H. (2015). Faktor-Faktor Yang Mempengaruhi Prokrastinasi Akademik Pada Mahasiswa Fakultas Psikologi UIN Sunan Gunung Djati Bandung. Psympathic, Jurnal Ilmiah Psikologi, 2(2). 123-132.

Feist \& Feist. (2010). Teori Kepribadian; Theories of Personality. Buku 1 edisi 7. (Penerjemah: Handrianto). Salemba Humanika: Jakarta

Ferrari, J. R., Johnson, J. L., \& McCown W. G. (1995). Procrastination and task avoidance: Theory, research, and treatment. New York: Plenum Press.

Flores-Crespo, P. (2007). Ethnicity, identity and educational achievement in Mexico. International Journal of Educational Development, 27(3), 331-339.

Galiesta, I. (2017). Pengaruh Fear Of Failure Terhadap Self Handicapping yang Dimediasi oleh SelfCompassion pada Mahasiswa Universitas Pendidikan Indonesia Penerima Bidikmisi. Skripsi. Universitas Pendidikan Indonesia. 
Haghbin, M., McCaffrey, A., \& Pychyl, T. A. (2012). The complexity of the relation between fear of failure and procrastination. Journal Rational-Emotive and Cognitive-Behavior Therapy, 30, 249263

Hayes, A. (2013). Introduction To Mediaton, Moderation And Conditional Process Analysis: A Regression-Based Approach. New York: The Guilford Press.

Hayes, A. F. (2018). Introduction to Mediation, Moderation, and Conditional Process Analysis (second edi). New York: The Guilford Press.

Januar, R. (2016). Hubungan Fear of Failure dan Prokrastinasi Akademik Dengan Kecurangan Akademik pada Mahasiswa Departemen Psikologi UPI. Skripsi. Universitas Pendidikan Indonesia.

JPPN.com. (2017). Biaya Kuliah Mahasiswa Bidik Misi Ditanggung 4 Tahun, Lampaui Batas Bagaimana? Diakses dari https://www.jpnn.com/news/biaya-kuliah-mahasiswa-bidik-misiditanggung-4-tahun-lampaui-batas-bagaimana.

Jose, P. E. (2013). Doing Statistical Mediation And Moderation. New York: The Guilford Press.

Kroger, J. (1993). Ego Identity: An Overview. Dalam K. Jane, Discussion on Ego Identity (hal. 1-20). United States of America: Lawrence Erlbaum Associates.

Kroger, J. (2008). Identity Development During Adolescent. New York: Rourletge.

Kroger, J., \& Marcia, J. E. (2011). The Identity Statuses: Origins, Meanings, and Interpretations. Dalam S. J. Schwartz, K. Luyckx, \& V. L. Vignoles, Handbook of Identity Theory and Research (hal. 3153). Norway: Springer.

Luyckx, K., Goosens, L., Soenens, B., \& Beyers, W. (2006). Unpacking Commitment and Exploration: Preliminary Validation of an Integrative Model of Late Adolescent Identity Formation. Journal of Adolescence, 41-60.

Mahmudah, S. 2013. Perbedaan Status Identitas Ditinjau Dari Persepsi Terhadap Pola Asuh Otoriter Di Panti Asuhan "X". Jurnal Penelitian Universitas Semarang, 166-172.

Marcia, J. E., \& Archer, S. L. (1993). Identity Status In Late Adolescents: Scoring Criteria. In J. E. Marcia, Ego Identity: A Handbook For Psychological Research. New York: Springer Verlag.

Marcia, J.E., Waterman, A.S., Matteson, D.R., Archer, S.L., and Orlofsky, J.L. (1993). Ego Identity; A Handbook for Psychological Research. New York: Springer Verlag.

Masyhuri \& Zainuddin. (2008). Metodologi Penelitian Pendekatan Praktis dan Aplikatif. Bandung: PT

Melgosa, J. (1987). Development and validation of occupational identity scale. Journal of adolescence, (10), 385-397.

Murdaningsih, D. (2015). 329 Mahasiswa bidikmisi Gagal lulus tepat waktu. Diakses dari https://m.republika.co.id/berita/pendidikan/dunia-kampus/15/ 08/06/nsndyv368-329-mahasiswabidik-misi-gagal-lulus-tepat-waktu.

Panduan Bidikmisi. (2018). Jakarta: Ristekdikti.

Purnomo, S. A., \& Izzati, U. A. (2013). HubunganAntara Internal Locus Of Control Dengan Prokrastinasi Akademik Pada Mahasiswa Angkatan 2008 Yang Menghadapi Skripsi Di Fakultas Ilmu Pendidikan Universitas Negeri Surabaya. Jurnal Psikologi Universitas Surabaya. Surabaya, 2 (3), $1-3$.

Putra, dkk. (2015). Peran Pengalaman Sebagai Pemoderasi Pada Pengaruh Pengetahuan Dan Sikap Wisatawan Mancanegara Terhadap Keputusan Pembelian Produk Wellness Tourism Di Kawasan Wisata Ubud, Kabupaten Gianyar. Jurnal IPTA. Vol. 3 No. 1.

Pychyl, T. A. (2008, 13 April). Teenagers, Identity Crises \& Procrastination. Dalam website Psychology Today: https://www.psychologytoday.com/blog/dont-delay/200804/teenagers-identity-crisesprocrastination.

Pradinata, S., \& Susilo, J. D. (2016). Prokrastinasi Akademik dan Dukungan Teman Sebaya pada Mahasiswa Fakultas Psikologi Universitas Katolik Widya Mandala Surabaya. Jurnal Experientia, $4(2), 85-95$.

Pratiwi, A. D. (2015). Prokrastinasi Akademik ditinjau dari Efikasi Diri Akademik dan Lama Studi pada Mahasiswa Jurusan Desain Komunikasi Visual Universitas Dian Nuswantoro. Jurnal Empati, 4 (4), 272-276. 
Pickhardt, C. E. (2009, 21 Juni). Procrastination: How Adolescents Encourage Stress. Dalam website Psychology Today: https://www.psychologytoday.com/blog/surviving-your-childsadolescence/200906/procrastination-how-adolescents-encourage-stress.

Ramadhani, S. (2016). Hubungan Antara Status Identitas Vokasional Dengan Perilaku Prokrastinasi Akademik Pada Mahasiswa Fakultas Ilmu Pendidikan Universitas Pendidikan Indonesia. S1 thesis, Universitas Pendidikan Indonesia.

Rozak, K. (2017). Dinamika Psikologis Mahasiswa yang Mengalami Prokrastinasi dalam Menyelesaikan Tugas Akhir Skripsi. Jurnal Bimbingan dan Konseling Edisi 2 Tahun ke-6. 154-177.

Safitri, A. (2018). Hubungan Dukungan Sosial Orang Tua Terhadap Prokrastinasi Akademik Dalam Menyelesaikan Skripsi. Jurnal Insight Fakultas Psikologi Universitas Muhammadiyah Jember. 165-184.

Schouwenburg, H. C. (1995). Academic Procratination: Theoretical notions, measurement, and research.

Schuler, J., Brandstätter, V. \& Baumann, N. (2013). Failure cue priming and impaired cognitive performance-Analyses of avoidance motivation as a mediator and fear of failure as a moderator. European Journal of Social Psychology, 43(5), 335-343.

Sebastian, I. (2013). Never be afraid: Hubungan antara fear of failure dan prokrastinasi akademik. Jurnal Ilmiah Mahasiswa Universitas Surabaya, 2(1), 1-8.

Setyadi, P., \& Mastuti, E. (2014). Pengaruh Fear Of Failure Dan Motivasi Berprestasi Terhadap Prokrastinasi Akademik Pada Mahasiswa Yang Berasal Dari Program Akselerasi. Jurnal Psikologi Kepribadian dan Sosial. 3 (1). 12-20.

Shanahan, M. J., \& Pychyl, T. A. (2007). An ego identity perspective on volitional action: Identity status, agency, and procrastination. Journal Personality and Individual Differences, (43) 901-911.

Steinberg, L. (2017). Adolescences 11th ed. NY: McGraw Hill.

Sugiono. (2004). Konsep, Identifikasi, Alat Analisis dan Masalah Penggunaan Variabel Moderator. Jurnal Studi Manajemen dan Organisasi, 1(2). 61-70

Sugiono, (2017). Metode penelitian kombinasi (Mixed Methods). Bandung: Alfabeta. Hal 63-68.

Sunanto, S. A., Asmaningrum, N., \& Simamora, R. H. (2013). Hubungan Pengenalan Status Identitas Remaja Dengan Aktualisasi Diri Di Pondok Pesantren Nurul Qarnain Kecamatan Sukowono Kabupaten Jember. Artikel Ilmiah Hasil Penelitian Mahasiswa, 1-8.

Solomon, L. J., \& Rothblum, E.D. (1984). Academic procrastination: Frequency and cognitivebehavioral correlates. Journal of Counseling Psychology, 31(4), 503-509.

Waterman, A. S. (1993). Overview Of The Identity Status Scoring Criteria. In J. E. Marcia, A. S. Waterman, D. R. Matteson, S. L. Archer, \& J. L. Orlofsky, Ego Identity: A Handbook For Psychosocial Research (Pp. 156-176). New York: Springer Verlag.

Wulan, D., \& Abdullah, S. (2014). Prokrastinasi Akademik dalam menyelesaikan skripsi. Jurnal SosioHumaniora, 5(1). 47-55. 